\title{
Integrating Youth Participation and Ecosocial Work: New Possibilities to Advance Environmental and Social Justice
}

\author{
Tania Schusler \\ Loyola University Chicago, tschusler@luc.edu
}

Amy Krings

Loyola University Chicago, akrings@luc.edu

Melissa Hernández

Follow this and additional works at: https://ecommons.luc.edu/socialwork_facpubs

Part of the Social Work Commons

\section{Author Manuscript}

This is a pre-publication author manuscript of the final, published article.

\section{Recommended Citation}

Schusler, Tania; Krings, Amy; and Hernández, Melissa. Integrating Youth Participation and Ecosocial Work: New Possibilities to Advance Environmental and Social Justice. Journal of Community Practice, 27, 3-4: 460-475, 2019. Retrieved from Loyola eCommons, Social Work: School of Social Work Faculty Publications and Other Works, http://dx.doi.org/10.1080/10705422.2019.1657537

This Article is brought to you for free and open access by the Faculty Publications and Other Works by Department at Loyola eCommons. It has been accepted for inclusion in Social Work: School of Social Work Faculty Publications and Other Works by an authorized administrator of Loyola eCommons. For more information, please contact ecommons@luc.edu. c) $($ () $\ominus$

This work is licensed under a Creative Commons Attribution-Noncommercial-No Derivative Works 3.0 License. (c) Taylor \& Francis, 2019. 


\section{Integrating youth participation and ecosocial work: New possibilities to advance environmental and social justice}

Tania Schusler, ${ }^{a}$ Amy Krings, ${ }^{b}$ and Melissa Hernández ${ }^{a}$

anstitute of Environmental Sustainability, Loyola University Chicago, Chicago, IL, USA; b School of Social Work, Loyola University Chicago, Chicago, IL, USA

\section{Corresponding author}

Tania Schusler, tschusler@luc.edu, Loyola University Chicago Institute of Environmental Sustainability, 1032 W. Sheridan Road, Chicago, IL 60660

\section{Copyright Agreement}

The Version of Record of this manuscript has been published and is available in Journal of Community Practice, 2019, DOI: 10.1080/10705422.2019.1657537.

\section{Complete Citation}

Tania Schusler, Amy Krings \& Melissa Hernández (2019) Integrating youth participation and ecosocial work: New possibilities to advance environmental and social justice, Journal of Community Practice, 27:3-4, 460-475, DOI: 10.1080/10705422.2019.1657537

\section{ABSTRACT}

This article reveals possibilities to expand the role of youth within ecosocial work practice. The Where I Stand Youth Summit held in Chicago, Illinois, provided a safe space for young people to reflect upon their understanding of, and roles within, social and environmental justice movements. Drawing upon critical youth empowerment theory and participant observation, we note that youth shared experiences of oppression across unique social identities, while displaying authentic communication, acceptance, and desire for solidarity. Re-defining what knowledge matters, along with intention and self-restoration, also emerged as critical to building young people's agency and power to effect social change.

KEYWORDS: Critical youth empowerment, environmental equity, equitable development, self-determination, social action, youth activism, youth engagement, youth voice 


\section{Integrating youth participation and ecosocial work: New possibilities to advance environmental and social justice}

Tania Schusler, Amy Krings, and Melissa Hernández

Climate change and environmental contamination disproportionately affect the health of marginalized groups, including racial and ethnic minorities and residents of divested communities (Mohai, Pellow, \& Roberts, 2009; Roberts \& Parks, 2006). Environmental hazards and a lack of access to environmental amenities are especially consequential for young people, because one's environment influences psychosocial and physical development (Evans, 2004, 2006; Markevych et al., 2014). These inequities - known as environmental injustice - reflect structural racism embedded in land use practices that disproportionately expose marginalized groups to toxins in their homes, schools and neighborhoods; limited enforcement of environmental and public health regulations; and land use decision-making processes that exclude vulnerable groups (Bullard, 1996; Cole \& Foster, 2001). Among people disadvantaged by systemic racism and classism, concerns about environmental health impacts also are at risk of being discredited by media and public officials (Krings, Kornberg, \& Lane, 2018).

Residents of affected communities advocate for environmental justice through campaigns that build local power and secure a fair distribution of environmental amenities (Bullard, 1993; Krings, Spencer, \& Jimenez, 2013; Krings \& Thomas, 2018). Social work that incorporates an ecosocial framework is well-suited to support these community-driven efforts. Understood to be emancipatory and political, ecosocial work calls upon social workers to act collectively with community members to support social and economic equality, human dignity, ecological sustainability, and collective wellbeing (Närhi \& Matthies, 2018; Peeters, 2012). Thus, to effectively practice ecosocial work, social workers must understand the perceptions of people, including youth, who are already working for social and environmental justice. Without understanding the rich history of environmental justice organizing and perceptions of those already involved, social workers might miss possibilities for partnership or, worse, inadvertently perpetuate environmental injustices by silencing, tokenizing, or objectifying marginalized community members. Yet the perceptions of youth activists, and the role of youth participation within ecosocial work broadly, have received limited attention to date. A comprehensive review of social work literature addressing environmental topics (1991-2015) found no title nor abstract including the words "youth," "young people," or "children" (Krings, Victor, Mathias, \& Perron, 2018a).

To begin to address this gap, this article examines the perspectives of youth who are actively working for environmental and social justice. Specifically, we report findings from the Where I Stand Youth Summit, a retreat held in 2018 in Chicago, Illinois. Drawing upon critical youth 
empowerment theory, we explore how youth and their adult mentors define social and environmental issues, consider opportunities for collaboration, and envision their own roles in enacting solutions. Our findings reveal new opportunities for ecosocial workers to support and strengthen youth participation within environmental justice movements.

\section{Youth participation aligns with ecosocial work}

Youth participation is a process of involving young people in the decisions that affect their lives (Checkoway \& Gutiérrez, 2006). Hart (1997) describes forms of youth participation that vary in the degree to which young people are able to make decisions and effect change. Non-participation in the forms of manipulation, decoration, and tokenism appears to involve youth participants; however, adults retain decision-making authority. Models of real participation include consultation, social mobilization, children-in-charge, and shared decision-making. In these models, young people influence the institutions and decisions that affect their lives. Different forms of real youth participation are suitable to different contexts, cultures, and youths' varying interests and capabilities (Hart, 1997).

Critical youth empowerment expands upon this notion of participation by conceptualizing empowerment as a multi-level construct in which "individuals, families, organizations, and communities gain control and mastery, within the social, economic, and political contexts of their lives, in order to improve equity and quality of life" (Jennings, Parra-Medina, Hilfinger Messias, \& McLoughlin, 2006, p. 32). Critical youth empowerment includes six key dimensions:

- A welcoming and safe environment in which youth experience freedom to be themselves, express creativity, voice opinions in decision-making, and feel ownership.

- Meaningful participation and engagement characterized by opportunities for youth to contribute authentically as they learn and try new roles and skills.

- Equitable power-sharing between youth and adults. Youth are afforded leadership roles with actual power to influence organizational or community decision-making.

- Engagement in critical reflection on interpersonal and sociopolitical processes. Critical reflection enables understanding the structures, processes, social values, and practices that participants seek to alter.

- Participation in sociopolitical processes in order to effect change. Critical youth empowerment involves action to address unjust structures, processes, social values, and practices. For example, youth picking up litter provides a useful civic service; however, to be considered critical youth empowerment, youth would reflect upon and act to change the structures and processes that produce waste.

- Integrated individual and community-level empowerment. As youth develop "a critical awareness of processes, structures, social practices, norms, and images that affect them," they determine "how to live productively within those social spaces or, better yet, how to change them for the benefit of all” (Jennings et al., 2006, p. 50). 
Critical youth empowerment, and youth participation more broadly, can benefit both youth and communities. Youth engagement can bolster participants' developmental assets (Schusler \& Krasny, 2010) and their understanding of complex issues, including conservation and the environment (Ballard, Dixon, \& Harris, 2017). Youth participation can also contribute to community and policy level change (Chawla, 2002; Sprague Martinez, Richards-Schuster, Teixeira, \& Augsberger, 2018). Youth who collaborate with adults to improve local environments and communities also may exhibit personal transformation (Schusler, Krasny, Peters, \& Decker, 2009).

Despite these benefits, supporting youth participation in decision-making and social change processes can be difficult. Barriers include perceptions held by some adults that youth lack capacity to be competent community builders or change agents (Finn \& Checkoway, 1998). Such characterizations can be especially damaging in places like Chicago where youth and adults can internalize news coverage that focuses on crime and violence, absent reporting about the assets within their communities. Additionally, adults who hold authority and ultimate responsibility for actions within youth programs may resist sharing decision-making power, in part because of organizational cultures, norms, policies, and structures (Schusler, Krasny, \& Decker, 2016; Zeldin, Camino, \& Mook, 2005). Limited time for critical reflection by both youth and adults also can limit opportunities for growth and empowerment (Jennings et al., 2006).

Thus, a need exists for research that increases the understanding of contexts and mechanisms that support widespread youth participation (Richards-Schuster \& Pritzker, 2015). This study examined how youth conceptualize their roles as agents of social change. Our findings rely on observational data collected during the Where I Stand Youth Summit, a two-and-a-half-day retreat for young people engaged in Chicago-based, youth-driven organizations working for social and environmental justice. The Where I Stand Youth Summit, particularly its embodiment of critical youth empowerment principles, provides guidance for ecosocial workers seeking to foster youth empowerment towards social and environmental justice.

\section{Research methods}

\section{Research design}

The research team included scholars of environmental sustainability (Schusler and Hernández) and social work (Krings) as well as the lead organizer of the Where I Stand Youth Summit (Anderson). The study's design and implementation reflect a participatory research process characterized by the equitable sharing of power between the academic and community-based team members in all methodological decisions (Checkoway \& Gutiérrez, 2006). A memorandum of understanding between the team members outlined the research objective; specific roles and 
responsibilities; data access, usage, and secure storage; and the research budget. In designing the research, Anderson, who is also the director of Sacred Keepers Sustainability Lab (https://www.sacredkeepers.org), a Chicago-based organization that engages youth in consciousness-raising related to intersections of the environment, culture, justice, and wellbeing, shared input from her conversations with the Sacred Keepers Youth Council. This participatory design ensured that the research complemented and contributed to the Summit's aims. The team co-constructed the research question: how do youth and their mentors understand the interconnectedness of environmental justice and social justice, the role of collaboration in movement building, and their own roles in moving forward social change? The research team also agreed upon the data collection method of participant observation and collaborated in data analysis, as described later. The research was approved by the Institutional Review Board of Loyola University Chicago.

It may benefit the reader to know the positionality of the research team members. Anderson, the Summit's lead organizer, is an African-American woman whose relationships with youth, parents, youth organizations, educators, community organizers, and activists made the Summit possible. Schusler and Krings are both white women and researchers at a private university in Chicago. Both have worked with youth as community practitioners, yet were largely outsiders in relation to the Summit's participants. Hernández is a Latina who, at the time of data collection, was an undergraduate student. Although considered a youth by some definitions, she was not from one of the participating youth groups; therefore, she had both insider and outsider status.

The research team selected participant observation as the data collection method because it positioned the researchers as co-learners, enabling them to listen deeply to the experiences and perceptions of youth as those unfolded in the context of the Summit. A fundamental distinction among observational strategies is the extent to which the observer also participates in the setting under study (Patton, 2002). Anderson co-facilitated the Summit with the Sacred Keepers Youth Council and the academic team members participated in the Summit to engage in learning and growing with the youth participants. During downtime, each observer wrote memos to document key themes. Data analyzed included field notes, memos, and event documents (e.g., recruitment materials, newsprint notes from the event, and identity crests created by the youth groups).

\section{Participants and the summit}

"Truth and justice seekers, it is time for us to gather to explore and connect our worlds, to deeply know how we best stand up in who we are, for one another, and for the healing of the planet," began a recruitment flyer for the Where I Stand Youth Summit. In addition to the Sacred Keepers Youth Council, Anderson recruited five youth groups to attend through her professional and personal networks using conversations, phone calls, e-mails, and flyers that described the Summit's purpose and format (Table 1). In all, twenty-three youth ages fourteen to nineteen 
participated along with eight adult mentors. These adult mentors included three youth group facilitators and five adults involved in the event's organization and sponsorship. During the Summit, some participants specifically referred to their racial or ethnic identities as African-American, Latinx, Native, or mixed race. Youth and adult mentors came from neighborhoods throughout Chicago, a highly segregated city (Novara, Loury, \& Khare, 2017), although most reported living in predominantly African-American or Latinx communities located on Chicago's south or west sides. For decades, public and private divestment has contributed to environmental injustices in these areas and they contain many of the city's most hazardous land uses (Pellow, 2004).

Table 1. Youth-driven organizations participating in the Where I Stand Summit held in Chicago, Illinois in April 2018.

\begin{tabular}{|l|l|}
\hline Organization & Social Change Focus \\
\hline Bodhi Spiritual Center Teens & encouraging unconditional love and spirituality \\
\hline Chi-Nations Youth Council & $\begin{array}{l}\text { raising awareness of cultural identity and } \\
\text { promoting a healthy lifestyle through arts, } \\
\text { activism, and education }\end{array}$ \\
\hline Sacred Keepers Youth Council & $\begin{array}{l}\text { engaging in environmental education and } \\
\text { organizing service-learning projects that } \\
\text { promote environmental justice and sustainability } \\
\text { in Chicago and Kenya }\end{array}$ \\
\hline $\begin{array}{l}\text { Student Voice and Activism } \\
\text { Fellowship }\end{array}$ & $\begin{array}{l}\text { conducting action research to improve } \\
\text { conditions within Chicago Public Schools }\end{array}$ \\
\hline Ujimaa Medics & $\begin{array}{l}\text { training people to provide first response care } \\
\text { until paramedics arrive when shootings, asthma } \\
\text { attacks, or other emergencies occur }\end{array}$ \\
\hline
\end{tabular}

Consistent with the process of critical youth empowerment, the Summit was designed to create a safe place for youth participants to try out new roles and engage in critical reflection about the structures, social practices, and images that affect them. Its design aimed to facilitate dialog while building connections between youth that would support their participation in sociopolitical processes for social and environmental justice (Table 1). Held in April 2018, the Summit lasted from Friday night until Sunday afternoon. Most participants lived, worked, socialized, and shared meals at the host site for the entire two and one-half days. Content included reflective discussions, skills-based workshops, community building hang outs, and self-care. Youth voices 
were front and center throughout, and all sessions, whether youth or adult-led, were facilitated by people of color.

At the start of the Summit, when all of the participants introduced themselves, Anderson introduced the academic researchers, vouched for their trustworthiness, described the research purpose, and explained that she and the research team gave careful consideration to acknowledge and reduce the power disparity that often exists between universities and local communities. In this way, the university researchers were described as co-learners rather than experts, and participants were provided the opportunity to ask questions, raise concerns, or offer suggestions. The research team did not promise confidentiality given that all interactions among participants occurred in group settings. The academic researchers did not have access to individually identifying data, unless participants shared it with the collective group.

\section{Analysis}

To analyze the data, the participant observers (Schusler, Krings, and Hernández) reviewed and discussed the field notes, documents, and artifacts. Each analyst inductively derived themes by coding and categorizing their own field notes to produce an analytic memo reflecting the research questions (Emerson, Fretz, \& Shaw, 2011). They discussed their analyses face-to-face one week following the Summit. Although the initial organizational scheme of each analyst differed, they identified the same ideas, moments, and interactions as salient. They continued to compare and contrast their analyses through writing in a shared document in an iterative process of increasingly focused coding to arrive at the themes presented in the Findings below. At key decision points, the analysts deliberated about how to represent the data until reaching consensus.

The credibility of the findings was enhanced by the observers' diligence in taking rich, descriptively detailed notes that avoided inference, as well as by triangulating data sources and their analysis across the three academic researchers. Member checking of that analysis further increased the findings' credibility. Anderson and the Sacred Keepers Youth Council collectively reviewed an original draft of this manuscript, which led to two key changes. First, we strengthened emphasis on the sense of support and solidarity that participants acknowledged across their different communities, racial identities, and priorities for social change. Second, we explained how the academic researchers navigated their role as outsiders by participating in the Summit on equal footing with, not above or apart from, the youth.

\section{Findings}

In the subsections below, we describe themes that reflect the substantive essence of the Where I Stand Summit. We organize these themes by the three dimensions of the research question: (1) interconnectedness between environmental and social justice, (2) collaboration in movement 
building, and (3) youths' roles in creating social change. Although we present the themes as distinct conceptual units, the phenomena that they represent inevitably intersect.

\section{Interconnectedness of environmental and social justice}

Three threads emerged as key points of intersection across young people's experiences: unique and shared identities, place and land, and self-determination.

\section{Unique and shared identities}

Youth discussed struggles with marginalization specific to their racial and ethnic identity groups. Such marginalization took the forms of segregation; gentrification; gun-violence; cultural repression; tokenism in classrooms; misinformation in education that reinforces stereotypes; exclusion from decision-making over land-use; and lack of access to healthcare facilities, natural resources, and acceptable school infrastructure. Far from a "pity party," these dialogs seemed to validate and motivate youth in their activism for social justice. As some voiced their personal stories, they recognized shared experiences of injustice across their diverse struggles. For example, despite possessing different racial identities and engaging in social activism around different issues, multiple youth shared the experience of being labeled "radical" by adults: "When people of color try to make change, they are often viewed as radical, but really, we're just trying to live ... . Society views something as radical when you're just trying to make sure you survive," explained a Native youth. An African American youth concurred, "I agree with that ... . At the end of the day nobody in here is hurting anybody. We're just trying to make places better for ourselves and others." These youth possessed unique individual identities and yet related to others through a shared identity as people of color in a society that promotes white privilege.

\section{Place and land}

"We're all related to the land; the only difference is that Indigenous people are on their ancestral lands," offered a Native mentor. The Native delegation explained that disconnecting people from the land is a tool of control by which colonizers disempower people of color. African American and Latinx youth identified connections between Natives' struggle to regain their rights to stolen ancestral lands and residents' efforts in their own neighborhoods to stay in their homes in the face of gentrification and/or deportation. The desire to influence decisions affecting the place one lives and the land to which one culturally connects arose as an important point of intersection across participants.

\section{Self-determination}

In discussions and skills-based workshops, participants deconstructed oppressive societal structures and sought to build young people's power towards realizing self-determination in their lands, lives, and communities: "Lots of people are talking recklessly about equity. We will define equity because we live inequity," emphasized a workshop facilitator. His words convey 
self-determination, or the right to influence decisions affecting oneself. He added that racial equity requires targeted investment in Black, Brown, and Indigenous communities to redress historical injustices.

\section{Collaboration in movement building}

One aim of the Summit was to enable youth to meet, learn about one another's work, and build relationships that could lead to future collaborations. We next describe three key facets of participants' interactions related to building cooperative relationships: authentic communication, loving acceptance, and solidarity.

\section{Authentic communication}

Young people exhibited a degree of authenticity uncommon in many adult conversations. They posed thoughtful questions and demonstrated vulnerability in sharing with one another challenging experiences and uncomfortable emotions. This authentic communication seemed to be enabled by the safe atmosphere created by Summit organizers and participants. Anderson opened the Summit by asking the youth to "be present" meaning:

not doing anything else while someone is talking besides being there and listening .... Someone may be talking about what's breaking them and we need to show love and attention and that we care and that what they're going through matters.

A youth added that showing respect through being present also involves "not showing judgment" through facial expressions or body language as well as spoken language. Being present invokes self-awareness, attentiveness, and reciprocity. Being present contributed to a safe climate to be deeply authentic, which in turn provided a foundation for building collaborations.

\section{Loving acceptance}

The Summit's emphasis on acceptance of self and others also contributed to a safe atmosphere and encouraged relationship building. Youth collectively developed group agreements. Among these were, "Respect my space, voice, boundaries," "Acceptance/be open," and "Judgment free zone." These rules recognize that feeling accepted enables fuller participation. By the Summit's conclusion, acceptance - cemented with essential and unconditional love - seemed to permeate the space. One of the youth groups led a closing activity in which participants gave and received loving gestures, such as a hug or pat on the shoulder (or a non-physical sign for those preferring no touch). Reflecting on this activity, a youth with tears rolling down his cheeks expressed, "I don't usually cry in front of people. This shows my comfort being in this group. I had been feeling so broken," at which point others approached to affirm him. A mentor said, "Everything starts with love ... . Take care of yourself and others' around you and the Earth, our home and 
sustenance ... .We can only be happy or live with love if we love our Earth and protect it so that it may protect us also."

\section{Solidarity}

An expressed desire for solidarity arose in part from youth recognizing connections between the injustices they experience:

Black and Brown communities seem more apart than alike, but we go through similar issues. It's hard to be in solidarity when you're taught that your issues are different. We have been pulled apart so much ... .It's hard to care about others' issues when you're so focused on the ones in your own community.

Participants identified the city's segregation as a substantial barrier to achieving solidarity. Youth lack opportunities to visit other neighborhoods and face pressing issues (e.g., violence, public health, environmental quality, displacement through gentrification, and educational inequity) in their own communities: "If you're only seeing DAPL [Dakota Access Pipeline] or only seeing Black violence, it's hard to see how we can be in solidarity. That requires education." Hence, it is important for youth to come together to learn about each other's issues and how they can support one another: "We have to consciously be aware of working together not against each other."

\section{Youths' roles in creating social change}

Acknowledging their right to social and environmental justice, several of the youth described how they act to attain that justice. We next elaborate on how young people - with their mentors' support - build and apply power to create positive social change through youth agency, knowledge, intention, and self-restoration.

\section{Youth agency}

"Everyone has potential to create change," read a crest created by one of the youth organizations. Formal presentations given by youth about their activism illustrated that they not only exert their own agency but also work to build other people's capacity for changing problematic situations. One youth group raised funds to travel to Kenya and assisted the Maasai people in building a water tank and planting trees to aid reforestation. These youth described feeling rewarded by their ability to be of service while also learning from the Maasai's wisdom and respecting the Maasai's self-determination. Another youth described the emergency first response organization that she created to address the absence of trauma centers on Chicago's south side. She trains people to perform first response aid and they in turn train others, developing a circle of learning and care. In these and other examples, youth use their agency to acquire power, such as resources or knowledge, which they then share with others. 


\section{Knowledge}

"The school system doesn't value what we learn outside of school, it's all about grades," said a youth. Whereas youth described schools as often rigid institutions that reinforce dominant standards of what knowledge is valued, many of the youth conceived of learning that takes place outside of schools (e.g. lived experiences, culture-specific collective memory, and activism and organizing work) as truly educational. Youth raised and critically examined questions like: what counts as knowledge? who is knowledge for? what knowledge is valuable? am I white washing myself to gain knowledge? The chasm between what counts as knowledge and what matters to youth is especially salient because youth recognized knowledge as essential to social change. For example, youth reconstructed a general expectation that education serves the purpose of an individual's upward mobility:

School tells us 'we need more Black lawyers and doctors.' No, what we need is more kids to be aware [of social justice issues]. If you will be a doctor or lawyer, serve some sort of justice, build a hospital in the hood, make the hood better.

Added another:

This [activism] work is preparing us to take on adult roles ... We are seen as the best and brightest in our communities and outside voices are telling us we're gonna 'get out of the hood.' No. That's your community. Go learn, and come back, and make it better. This work prepares us to be active in making our communities better.

\section{Intention}

The Summit encouraged young people's intentionality through reflective discussions and mindfulness practices designed to ground them within themselves. For instance, Anderson initiated a morning discussion by inquiring, "How do you greet the day?" She stressed that whether you wake up in a good or bad mood, the intentions you set affect how you experience that day. Being aware of one's energy and practices like focused breathing were infused throughout the Summit. For example, a dance movement therapist highlighted that our internal state affects what we bring to the external world. She asked everyone to take a soft gaze or close their eyes and mindfully scan each part of their body from the feet up to the head. This led into drawing, reflecting, and a collective activity involving expression through movement. Afterward, youth reported feeling relaxed and uplifted. This activity reinforced that through mindful, internal attention one can move through and exert agency in the external world. 


\section{Self-restoration}

Mindfulness practices not only build intentionality; they can nurture the self-care required to sustain social change activism. Youth expressed deep satisfaction from their activism - "It doesn't feel like work. This is just how I live" - but also recognized that avoiding burnout requires caring for themselves: "The transitions between so many worlds that we're in exhausts us ... . We're always playing the moderator, molding, adapting; our hands get tired ... . How do we replenish?" Self-restoration - referred to by youth as "self-care," "healing," and "replenishing" - took multiple forms, including finding common ground in shared identities, practicing loving acceptance of self and others, and building solidarity, as described earlier.

Some youth perceived activism itself as restorative. For instance, the young person who developed the emergency first-response program described how her work helps her heal the wound caused by the loss of a childhood friend: "You can be wounded by a lot of things. By being active in your community, it's practicing self-care ... [transforming] a traumatizing situation from fear to empowerment." Youths' roles as activists for social change intertwine with their need for care, healing, and personal replenishment, thereby sustaining their agency.

\section{Potential relationships across themes}

Because this research was not designed to examine cause-effect relationships, we cannot definitively discern associations among the phenomena observed during the Summit. Nonetheless, it is useful for identifying future research directions to consider how young people's insights about the interconnectedness of social and environmental justice relate to their perceptions of collaboration in movement building and their own roles in moving forward social change. Figure 1 suggests potential connections among the themes that emerged from participant's dialogs and interactions with one another during the Summit. 


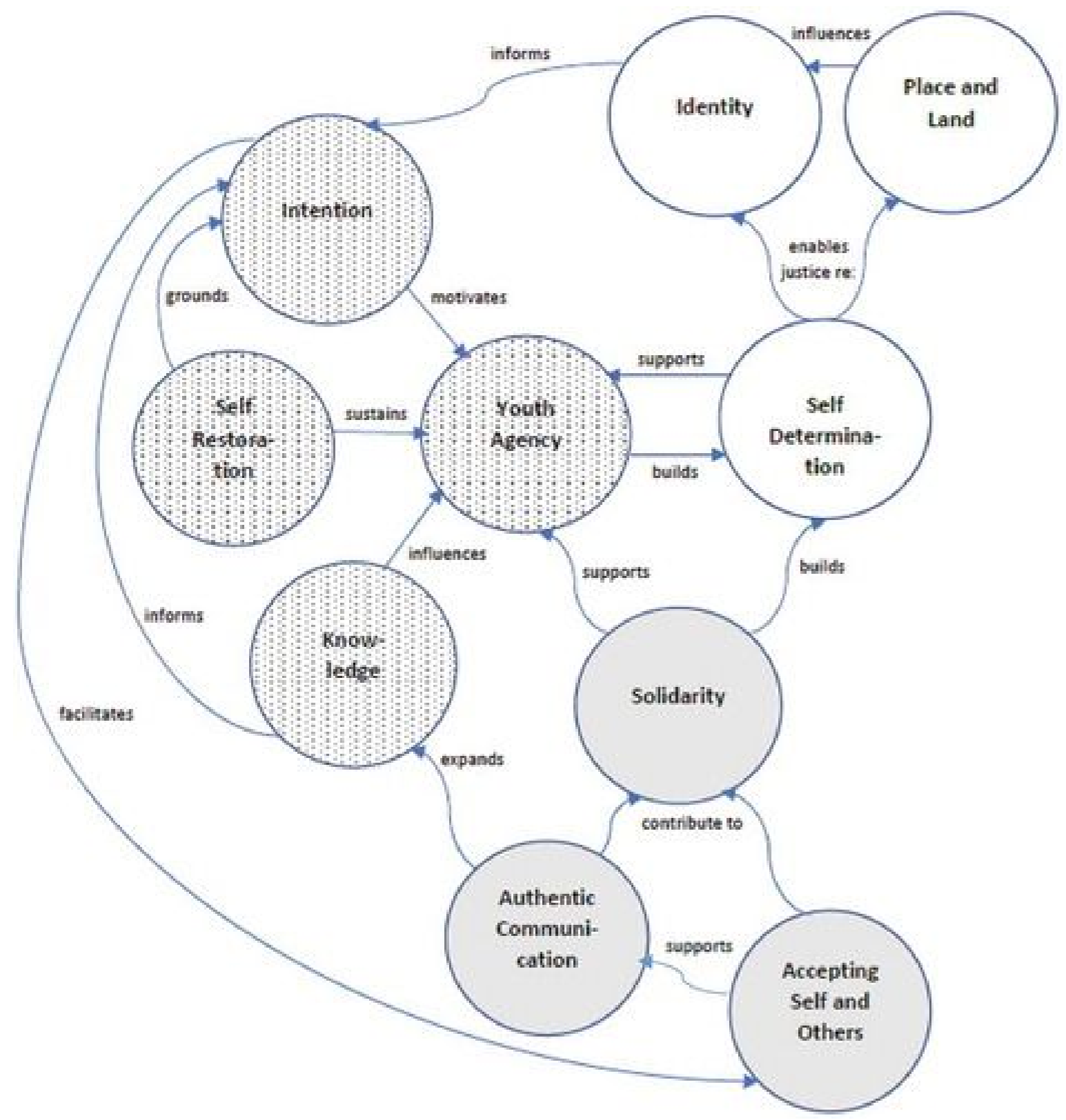

Figure 1. Concept map based upon key themes evident during the Where I Stand Youth Summit. This diagram illustrates how youth can build agency and solidarity towards self-determination related to social and environmental justice. Arrows indicate potential interactions between phenomena and suggest avenues for future research. 


\section{Discussion}

Ecosocial work practice engages with community members to promote human dignity, ecological sustainability, and the empowerment and liberation of all people (Coates \& Gray, 2012; Närhi \& Matthies, 2018). In this way, ecosocial work can be understood as a form of anti-oppressive social work (Dominelli, 2002) that also is consistent with the values and principles of the environmental justice movement (Bryant, 1995; Bullard, 1996) and critical youth empowerment (Jennings et al., 2006). Although social work research has examined interventions that can mitigate harm caused by environmental crises and natural disasters (Krings, Victor, Mathias, \& Perron, 2018b; Mason, Shires, Arwood, \& Borst, 2017), additional research is needed to develop methods that proactively engage people in critical reflection and action relating to their self-determination, health, and natural and built environments. In particular, youth of color living in communities with high levels of poverty, who are disproportionately impacted by environmental hazards (Evans, 2004), merit a seat at decision making tables relating to their communities.

To this end, the findings from the Where I Stand Youth Summit can inform ecosocial work practice. The Where I Stand Summit demonstrated the ability of youth to engage critically with questions of justice, power, resource distribution, and social change. These young people's perspectives can help ecosocial workers and other change agents to be thoughtful and deliberate in their efforts to partner with youth in transforming the world. The Summit embodied dimensions of critical youth empowerment in its welcoming and safe environment, meaningful participation, equitable power-sharing between youth and adults, and - most notably participants' engagement in critical reflection on interpersonal and sociopolitical processes. The Summit provided opportunities for youth and adult allies to learn from each other about the social change processes they participate in through their respective organizations. It also encouraged reflection upon the integration of individual and community-level empowerment, as participants considered how their identities and values relate to social structures, narratives, and competing visions for the future of their communities. By providing the physical space, time, and a facilitated process for discovering how to stand in solidarity with others acting for social and environmental justice, the Summit addressed a key barrier to critical youth empowerment: the lack of opportunity for critical reflection (Jennings et al., 2006). Indeed, Anderson and the Sacred Keepers Youth Council, in communication with other organizations, are planning for a future Summit of longer duration that will allow more time for individual and collective reflection to occur.

\section{Conclusion}

As social workers consider how the profession can contribute toward the United Nations' Sustainable Development Goals of ending poverty, protecting the planet, and ensuring prosperity for all (Jones \& Truell, 2012), effective interventions must engage with the people affected by 
environmental impacts (Teixeira \& Krings, 2015). The Where I Stand Youth Summit illustrates the potential for integrating youth participation into ecosocial work - fields that both view the participation of impacted groups as a right. The Summit offered the opportunity to understand how youth interpret (and re-interpret or re-write) society's dominant narratives and how they advocate for equity in the policies, institutions, and decisions affecting them. This research adds to a body of literature demonstrating the benefit - and perhaps necessity - of youth participation (Checkoway et al., 2003). Future research investigating youth participation within ecosocial work could examine the pathways indicated by the arrows in Figure 1, which suggest interactions between phenomena. For example, how does authentic communication contribute to knowledge and solidarity and, in turn, support youths' agency toward building power for self-determination in the decisions affecting their lives, lands, and communities? The answers to such questions can further inform ecosocial workers in facilitating critical youth empowerment.

\section{Acknowledgments}

We thank co-researcher Toni Anderson of Sacred Keepers Sustainability Lab for her vision and creativity designing the Where I Stand Youth Summit; the Sacred Keepers Youth Council, who co-led the Summit; and the other participating youth groups: Bodhi Spiritual Center Teens, Chi-Nations Youth Council, Student Voice and Activism Fellowship, and Ujimaa Medics. We also thank those who led workshops or otherwise contributed: Alliance for the Great Lakes, Monimia Macbeth of Creative Passages, Jhmira Alexander of 29Eleven Consulting, Toni'Mono Monix, Seva Gandhi and Samantha Sainsbury of the Institute of Cultural Affairs, Stacy Gibson of Transform the Collective, Kels the Yogi, Olatunji Oboi Reed of Equiticity, and Kenisha Jamison of Waist Ware Circles. A Faculty Fellowship Award from Loyola University Chicago's Center for the Human Rights of Children provided funding for this research.

\section{Disclosure statement}

No potential conflict of interest was reported by the authors.

\section{References}

1. Ballard, H. L., Dixon, C. G. H., \& Harris, E. M. (2017). Youth-focused citizen science: Examining the role of environmental science learning and agency for conservation. Biological Conservation, 208, 65-75. doi:10.1016/j.biocon.2016.05.024

2. Bryant, B. (Ed.). (1995). Environmental justice: Issues, policies, and solutions. Washington, DC: Island Press.

3. Bullard, R. D. (1993). Confronting environmental racism: Voices from the grassroots. Cambridge, MA: South End Press.

4. Bullard, R. D. (1996). Environmental justice: It's more than waste facility siting. Social Science Quarterly, 77(3), 493-499. 
5. Chawla, L. (Ed.). (2002). Growing up in an urbanising world. London, England: Earthscan.

6. Checkoway, B., \& Gutiérrez, L. (2006). Youth participation and community change. Journal of Community Practice, 14(1-2), 1-9. doi:10.1300/J125v14n01_01

7. Checkoway, B., Richards-Schuster, K., Abdullah, S., Aragon, M., Facio, E., Figueroa, L., ... White, A. (2003). Young people as competent citizens. Community Development Journal, 38(4), 298-309. doi:10.1093/cdj/38.4.298

8. Coates, J., \& Gray, M. (2012). The environment and social work: An overview and introduction. International Journal of Social Welfare, 21(3), 230-238. doi:10.1111/j.1468-2397.2011.00851.x

9. Cole, L. W., \& Foster, S. R. (2001). From the ground up: Environmental racism and the rise of the environmental justice movement. New York: New York University Press.

10. Dominelli, L. (2002). Anti-oppressive social work theory and practice. New York, NY: Palgrave Macmillan.

11. Emerson, R., Fretz, R., \& Shaw, L. (2011). Writing ethnographic fieldnotes (2nd ed., Chicago guides to writing, editing, and publishing). Chicago, IL: The University of Chicago Press.

12. Evans, G. W. (2004). The environment of childhood poverty. American Psychologist, 59(2), 77-92. doi:10.1037/0003-066X.59.2.77

13. Evans, G. W. (2006). Child development and the physical environment. Annual Review of Psychology, 57, 423-451. doi:10.1146/annurev.psych.57.102904.190057

14. Finn, J. L., \& Checkoway, B. (1998). Young people as competent community builders: A challenge to social work. Social Work, 43(4), 335-345. doi:10.1093/sw/43.4.335

15. Hart, R. A. (1997). Children's participation: The theory and practice of involving young citizens in community development and environmental care. London, England: Earthscan.

16. Jennings, L. B., Parra-Medina, D. M., Hilfinger Messias, D. K., \& McLoughlin, K. (2006). Toward a critical social theory of youth empowerment. Journal of Community Practice, 14(1/2), 31-55. doi:10.1300/J125v14n01_03

17. Jones, D. N., \& Truell, R. (2012). The global agenda for social work and social development: A place to link together and be effective in a globalized world. International Social Work, 55(4), 454-472. doi:10.1177/0020872812440587

18. Krings, A., Kornberg, D., \& Lane, E. (2018). Organizing under austerity: How residents’ concerns became the Flint water crisis. Critical Sociology, 45(4-5), 583-597. doi:10.1177/0896920518757053

19. Krings, A., Spencer, M. S., \& Jimenez, K. (2013). Organizing for environmental justice: From bridges to taro patches. In S. Dutta \& C. Ramanathan (Eds.), Governance, development, and social work (pp. 186-200). London, England: Routledge. doi:10.4324/9780203796009 
20. Krings, A., \& Thomas, H. (2018). Integrating green social work and the U.S. environmental justice movement: An introduction to community benefits agreements. In L. Dominelli (Ed.), The Routledge handbook of green social work (pp. 397-406). New York, NY: Routledge. doi:10.4324/9781315183213

21. Krings, A., Victor, B., Mathias, J., \& Perron, B. (2018a). Environmental social work in the disciplinary literature, 1991-2015. Unpublished raw data.

22. Krings, A., Victor, B., Mathias, J., \& Perron, B. (2018b). Environmental social work in the disciplinary literature, 1991 - 2015. International Social Work. doi:10.1177/0020872818788397

23. Markevych, I., Tiesler, C. M., Fuertes, E., Romanos, M., Dadvand, P., Nieuwenhuijsen, M. J., \& Heinrich, J. (2014). Access to urban green spaces and behavioural problems in children: Results from the GINIplus and LISAplus studies. Environment International, 71, 29-35. doi:10.1016/j.envint.2014.06.002

24. Mason, L. R., Shires, M. K., Arwood, C., \& Borst, A. (2017). Social work research and global environmental change. Journal of the Society for Social Work and Research, 8(4), 645-672. doi:10.1086/694789

25. Mohai, P., Pellow, D., \& Roberts, J. T. (2009). Environmental justice. Annual Review of Environment and Resources, 34, 405-430. doi:10.1146/annurev-environ-082508-094348

26. Närhi, K., \& Matthies, A. L. (2018). The ecosocial approach in social work as a framework for structural social work. International Social Work. 61, 490-502. doi: $10.1177 / 0020872816644663$

27. Novara, M., Loury, A., \& Khare, A. (2017). The cost of segregation. Chicago, IL: Metropolitan Planning Council.

28. Patton, M. Q. (2002). Qualitative research and evaluation methods (3rd ed.). Thousand Oaks, CA: Sage Publications.

29. Peeters, J. (2012). The place of social work in sustainable development: Towards ecosocial practice. International Journal of Social Welfare, 21(3), 287-298. doi:10.1111/j.1468-2397.2011.00856.x

30. Pellow, D. N. (2004). Garbage wars: The struggle for environmental justice in Chicago. Cambridge, MA: MIT Press.

31. Richards-Schuster, K., \& Pritzker, S. (2015). Strengthening youth participation in civic engagement: Applying the Convention on the Rights of the Child to social work practice. Children and Youth Services Review, 57, 90-97. doi:10.1016/j.childyouth.2015.07.013

32. Roberts, J. T., \& Parks, B. (2006). A climate of injustice: Global inequality, north-south politics, and climate policy. Cambridge, MA: MIT Press.

33. Schusler, T. M., \& Krasny, M. E. (2010). Environmental action as context for youth development. Journal of Environmental Education, 41(4), 208-223. doi:10.1080/00958960903479803 
34. Schusler, T. M., Krasny, M. E., \& Decker, D. J. (2016). The autonomy-authority duality in shared decision-making with youth. Environmental Education Research, 23, 533-552. doi:10.1080/13504622.2016.1144174

35. Schusler, T. M., Krasny, M. E., Peters, S. J., \& Decker, D. J. (2009). Developing citizens and communities through youth environmental action. Environmental Education Research, 15(1), 111-127. doi:10.1080/13504620802710581

36. Sprague Martinez, L., Richards-Schuster, K., Teixeira, S., \& Augsberger, A. (2018). The power of prevention and youth voice: A strategy for social work to ensure youths' healthy development. Social Work, 63(2), 135-143. doi:10.1093/sw/swx059

37. Teixeira, S., \& Krings, A. (2015). Sustainable social work: An environmental justice framework for social work education. Social Work Education: The International Journal, 34(5), 513-527. doi:10.1080/02615479.2015.1063601

38. Zeldin, S., Camino, L., \& Mook, C. (2005). The adoption of innovation in youth organizations: creating the conditions for youth-adult partnerships. Journal of Community Psychology, 33(1), 121-135. doi:10.1002/jcop.20044 